\title{
Meta-analysis of the income and price elasticities of gasoline demand: public policy implications for Latin America
}

\author{
Luis Miguel Galindo, Joseluis Samaniego, José Eduardo \\ Alatorre, Jimy Ferrer Carbonell and Orlando Reyes
}

SUMMARY

By means of a meta-analysis, this article sets out to estimate average values for the income and price elasticities of gasoline demand and to analyse the reasons for the variations in the elasticities reported by the literature. The findings show that there is publication bias, that the volatility of elasticity estimates is not due to sampling errors alone, and that there are systematic factors explaining these differences. The income and price elasticities of gasoline demand differ between the short and long run and by region, and the estimation can appropriately include the vehicle fleet and the prices of substitute goods, the data types and the estimation methods used. The presence of a low price elasticity suggests that a fuel tax will be inadequate to control rising consumption in a context of rapid economic growth.

KEYWORDS

JEL CLASSIFICATION

AUTHORS
Gasoline, supply and demand, prices, consumption, econometric models, Latin America

C83, Q41, Q48

Luis Miguel Galindo is Chief of the Climate Change Unit of the Sustainable Development and Human Settlements Division, EcLAc. luismiguel.galindo@cepal.org

Joseluis Samaniego is Chief of the Sustainable Development and Human Settlements Division, Eclac. joseluis.samaniego@cepal.org

José Eduardo Alatorre is an economic affairs officer with the Sustainable Development and Human Settlements Division, EcLAc. joseeduardo.alatorre@cepal.org

Jimy Ferrer Carbonell is an economic affairs officer with the Sustainable Development and Human Settlements Division, EcLAc. jimy.ferrer@cepal.org

Orlando Reyes is a researcher with the Sustainable Development and Human Settlements Division, eclac. orlando.reyes@cepal.org 


\section{I}

\section{Introduction}

Gasoline consumption is indispensable to the workings of modern economies, but it is also associated with a number of negative externalities, such as vehicle traffic, air pollution and climate change (Steenhof and others, 2006; Galindo, 2008; Reyes, 2009). Different projections based on business-as-usual scenarios suggest that gasoline consumption will increase substantially over the coming years, intensifying these negative externalities (Calthrop and Proost, 1998; Galindo, 2008; Kim and others, 2011). This is particularly relevant to Latin America, where the negative externalities from urban transport, for example, are already particularly large and are very likely to worsen in a context of rapid economic growth (Alves and Bueno, 2003; Galindo, 2008).

In this context, it is essential to identify the factors influencing the evolution of gasoline consumption and the magnitude of their effects. The empirical literature on fuel demand is large and very varied, and encompasses different countries, regions, periods, and even diverse estimation methodologies. This has been reflected in the numerous econometric estimates carried out for the response sensitivities of two fundamental factors in the evolution of gasoline consumption: income elasticity

$\square$ This study is one of a set produced as part of the "Fiscal Policy and Climate Change" programme, with financing from the German Agency for International Cooperation (GIZ). The opinions expressed herein are the exclusive responsibility of the authors and may not coincide with those of ECLAC nor reflect the official views of any governments, institutions or donors mentioned in the study. The authors are grateful for the comments of Fernando Filgueira, Gabriel Porcile and José Javier Gómez. The usual error disclaimer applies. and price elasticity. These elasticities are essential for identifying and simulating, for example, the consequences of different economic growth scenarios or the application of a fuel tax. Accordingly, a vital part of constructing a low-carbon sustainable development strategy is to identify them appropriately.

Systematically reviewing all the information available in the various studies on gasoline demand is a complex task, but it can be synthesized through a metaanalysis that summarizes, integrates and interprets the findings of different empirical studies (Van den Bergh and others, 2010; Cumming, 2012; Stanley, 2001) with a view to obtaining a weighted average estimator that incorporates the combined effect of the values from each study, with weightings allocated to reflect the accuracy (variance or standard error) of their respective results (Sterne, 2009). This method can also be used to arrive at general inferences and explore the heterogeneity of findings across the different studies (Borenstein and others, 2009; Sáez and others, 2001).

Thus, the main purpose of this article is to carry out a meta-analysis for the income and price elasticities of gasoline demand and draw out some public policy implications for Latin America. The article contains four sections. Following the Introduction, section II discusses gasoline demand and the factors determining it, and explains what a meta-analysis is. Section III sets out the estimates of the combined coefficients obtained from the meta-analysis and the results of the meta-regressions, and presents some public policy considerations. Lastly, section IV offers conclusions and general remarks.

\section{II}

\section{Meta-analysis of gasoline demand}

Gasoline consumption is an essential input for goods transportation and population mobility in modern economies. The evolution of its demand can be modelled like any other demand function (Deaton and Muellbauer, 1980; Varian, 1993) (equation (1)). In other words, demand for gasoline is a function of the evolution of spending (for which income is sometimes used as a proxy), its price and the prices of substitute and complementary goods, as well as a set of other factors, such as socioeconomic and demographic characteristics, the vehicle fleet, the 
urban structure or specific regulations on urban mobility and automobile use (Kayser, 2000; Dahl, 2012; Galindo, 2005; Reyes, 2009; Alves and Bueno, 2003):

$$
\operatorname{gas}_{i t}=F\left(y_{i t}, p g_{i t}, p_{i t}, \operatorname{cont}_{j i t}\right)
$$

where gas $_{i t}$ represents demand for gasoline, $y_{i t}$ is the spending or income variable, $p g_{i t}$ is its relative price, $p_{i t}$ are the prices of goods that are substitutes or complements for gasoline, and cont $_{j i t}$ are other relevant control variables. Subscript $t$ represents time, $i$ the different agents and $j$ the control variables. The economic literature suggests that income elasticity should be positive and price elasticity negative. In other words, an increase in total spending or income will be accompanied by an increase in gasoline consumption, while a rise in its price translates into a drop in its demand. However, a great variety of econometric estimates have been carried out for equation (1) using different specifications, methods, periods, countries, regions or economic agents (Espey, 1998). This is reflected by differences in the specific values yielded by estimates of the income and price elasticities of gasoline demand, creating a good deal of uncertainty from a public policy perspective.

These different income and price elasticities of gasoline demand, their volatility and any publication bias $^{1}$ can be analysed and synthesized through a metaanalysis, ${ }^{2}$ which is a combined statistical analysis of the body of empirical research and findings on a specific subject, incorporating all available information to identify common characteristics, average effects and the sources of heterogeneity in these effects (Stanley, 2001; Lipsey and Wilson, 2001). Each study estimates an effect $\left(\theta_{i}\right),{ }^{3}$ namely the size effect or the treatment effect, and a corresponding variance $\left(V_{\theta i}\right)$. These statistics can be used to obtain a weighted average of the studies, known as the summary size effect, with greater weight normally being assigned to more accurate studies, this accuracy being

\footnotetext{
${ }^{1}$ Publication bias exists when studies that are not included in the meta-analysis are systematically different from those that are. There is evidence that this can happen, as studies reporting larger effects (elasticities, for example) are more likely to be published than studies reporting smaller effects.

${ }^{2}$ Meta-analyses have also been criticized on the grounds that different findings are difficult to combine and an artificial variability of results may be generated (Lipsey and Wilson, 2001).

3 The objective of meta-analyses is often the coefficient known as the size effect, which identifies the magnitude of the effect being considered in the group of studies: $g=\left(\mu_{e}-\mu_{c}\right) / \sigma$, where $g$ is the size effect, $\mu_{e}$ and $\mu_{c}$ are the averages of the experimental and control groups, respectively, and $\sigma$ is the standard deviation of the control group (Stanley, 2001).
}

associated with the standard error of the effect (Lipsey and Wilson, 2001). ${ }^{4}$ However, estimates of income and price elasticities may present excessive volatility that is not just a consequence of sampling error, and may also have a publication bias resulting from preference being given to economic estimation studies that are consistent with economic theory, earlier estimates, or both.

Meta-regression analyses (MRA) can be used to identify systematic factors affecting the volatility of estimates and publication bias (Van den Bergh and others, 2010; Cumming, 2012). There are different types of metaregression estimates; this study uses a Heckman-type meta-regression based on the mixed-effects model that corrects for publication bias (Van den Bergh and others, 2010; Cumming, 2012; Havranek and others, 2012). Also reported for reference purposes are estimates of fixed, random and Huber-White effects, as these can be used to correct for heteroskedasticity and autocorrelation problems due to production clusters (Williams, 2000; Wooldridge, 2002). In addition, the estimates are weighted by the inverse standard deviation to reduce problems of heteroskedasticity (Lipsey and Wilson, 2001). Each of these estimation methods presents some limitations, with the fixed, random, mixed and Huber-White effects models using a variety of fairly restrictive assumptions, for example (Abreu and Florax, 2005). At the same time, the statistical significance of the fixed- and mixed-effects models needs to be handled with caution, while HuberWhite estimation does not efficiently employ all available information (Abreu and Florax, 2005).

The size effect of the income and price elasticities of gasoline demand is obtained from a regression model represented in equation (2) (Stanley and Jarrell, 1989; Paterson and Canam, 2001):

$$
Y=X \beta+\varepsilon
$$

where $Y$ is a vector (nx1) containing the independent variables (e.g., gasoline demand), $X$ is a vector (nxm) of explanatory variables, $\beta$ is the vector $(\mathrm{mx} 1)$ of estimated coefficients and $\varepsilon$ is a vector $(\mathrm{nx} 1)$ of the error term.

Thus, the set of estimated elasticities are distributed randomly (in the absence of publication bias) around the real elasticity value, irrespective of the standard error (equation (3)) (Doucouliagos and Stanley, 2009; Stanley, 2008):

$$
b_{i}=\beta_{0}+w_{i}
$$

\footnotetext{
${ }^{4}$ There are also multivariate meta-analyses (Lipsey and Wilson, 2001).
} 
where $b_{i}$ represents the estimated elasticities and $\beta_{0}$ the actual elasticity value, and $w_{i}$ is the error term.

In cases where the estimated elasticities present a publication bias, it is possible to use a meta-regression with mixed effects and Heckman's two-step procedure (Havranek and others, 2012). This procedure uses the characteristics of a control sample to estimate potential bias with a probit or logit model, so that in a second step the Mills ratio can be included in the final equation (Heckman, 1979; Angrist and Pischke, 2009). There is no counterfactual available in the meta-regression, but the heterogeneity of the standard deviation can be used to identify the econometric equation, replacing the inverse Mills ratio (Stanley, 2001).

Thus, equation (3) can be reformulated ${ }^{5}$ in the presence of publication bias to include both the real elasticity value and this bias. This is represented in equation (4) (Stanley, 2001; Havranek and others, 2012; Doucouliagos and Stanley, 2009):

$$
b_{i}=\beta_{0}+\beta_{1} * S E\left(b_{i}\right)+u_{i}, \quad u_{i} / S E\left(b_{i}\right) \sim N\left(0, \delta^{2}\right)
$$

where $b_{i}$ is elasticity, $S E$ is the standard error for each estimate included in the meta-analysis, $\beta_{0}$ represents average real elasticity, $\beta_{1}$ estimates the magnitude of the bias and $u_{i}$ is the error term. A significant value for $\beta_{1}$ implies bias in the estimates (Havranek and others, 2012; Stanley, 2008). Equation (4) is estimated by weighted least squares to reduce possible heteroskedasticity problems (Havranek and others, 2012; Stanley, 2008). This is represented in equation (5), which identifies publication bias in the $\beta_{1}$ coefficient. This equation also allows the statistical significance of real elasticity ( $\beta_{0}$ coefficient) to be observed, once publication bias has been eliminated. It is worth noting that Monte Carlo simulations have shown its value to have a downward bias (Stanley, 2008; Stanley and Doucouliagos, 2011).

$$
\frac{b_{i}}{S E\left(b_{i}\right)}=t_{i}=\frac{\beta_{0} * 1}{S E\left(b_{i}\right)}+\beta_{1}+\xi_{i}, \quad \xi_{i} / S E\left(b_{i}\right) \sim N\left(0, \sigma^{2}\right)(5)
$$

Equation (5) can be modified to incorporate the presence of volatility in the estimates across studies (Havranek and others, 2012). Thus, equation (6) can be used to obtain the direction, magnitude and statistical

\footnotetext{
5 The approximation uses a Taylor polynomial (Apostol, 1967) such that $b_{1}=\beta_{1}+\sum{ }^{k} \alpha_{k} S E_{i}^{k}+v_{i}$ (Stanley and Doucouliagos, 2012).
}

significance of the bias by way of the $\beta_{1}$ coefficient and statistical significance, besides the publication bias and the mean effect estimated by the $\beta_{0}$ coefficient (Havranek and others, 2012):

$t_{i j}=\frac{\beta_{0} * 1}{S E\left(b_{i j}\right)}+\beta_{1}+\xi_{j}+\varepsilon_{i j}, \quad \varepsilon_{i j} / S E\left(b_{i j}\right), \xi_{j} \sim N(0, \theta)$

where subscript $i$ and $j$ represent the estimates and studies. Total errors $\left(\zeta_{i j}\right)$ thus include the part corresponding to random effects at the study level $\left(\xi_{j}\right)$ and errors at the estimation level $\left(\varepsilon_{i j}\right)$, where $\operatorname{var}\left(\xi_{i j}\right)=\psi+\theta$ and $\psi$ represents between-studies variance and $\theta$ within-studies variance. The variance of these two errors is added together because they are deemed to be independent.

Consequently, the real magnitude of average elasticity $\left(\beta_{0}\right)$ can be estimated with an augmented equation, known as Heckman's mixed-effects meta-regression, which contains a fixed-effects part captured in $\beta_{1}$ and a random part $\left(\zeta_{i}\right)$ (Stanley and Doucouliagos, 2012), ${ }^{6}$ and where the relationship between the standard errors and publication bias is assumed to be quadratic (Stanley, 2008; Stanley and Doucouliagos, 2011):

$$
\begin{gathered}
t_{i j}=\frac{\beta_{0} * 1}{S E\left(b_{i j}\right)}+\beta_{1} S E+\xi_{j}+\varepsilon_{i j}, \quad \xi_{j} / \operatorname{SE}\left(b_{i j}\right) \sim N(0, \psi), \\
\varepsilon_{i j} / \operatorname{SE}\left(b_{i j}\right), \xi_{j} \sim N(0, \theta)
\end{gathered}
$$

where $\beta_{0}$ measures the magnitude of average elasticity corrected for bias and $\beta_{1}$ represents the magnitude of the bias. It is also possible to identify some of the factors influencing the volatility of the estimates and their publication bias using equation (8) (Havranek and others, 2012; Van den Bergh and others, 2010; Phillips and Goss, 1995):

$$
t_{i j}=\frac{\beta_{0} * 1}{S E\left(e_{i j}\right)}+\beta_{1}+\sum_{k=1}^{k} \alpha_{k} Z_{i k}+\xi_{j}+\varepsilon_{i j}
$$

where $\beta_{1}$ represents publication bias and $\alpha_{k}$ are the coefficients of vector $Z_{i k}$ in the meta-regression, which includes the variables that affect volatility and are uncorrelated with the selection processes of studies

\footnotetext{
6 This is similar to a random panel data model (Havranek and others, 2012).
} 
(Doucouliagos and Stanley, 2009; Stanley and Jarrell, 1989). Subscript $i$ indicates the value taken by the variable in each study $i$. Vector $Z_{i k}$ includes a number of factors, such as the fact of an estimate being for an Organization for Economic Cooperation and Development (OECD) country (other than Chile and Mexico), the vehicle fleet, the prices of substitute or complementary goods as an explanatory variable in estimating gasoline demand, and the estimation method used, differentiating between panel, cross-sectional and time series data.

The statistical significance test for $\alpha_{0}$ is known in the literature as the funnel asymmetry test (FAT), and that for the statistical significance of $\beta_{0}$ as the precision effect test (PET) (Doucouliagos and Stanley, 2009; Stanley, 2005 and 2008). Thus, meta-regression analysis (equation (8)) is known as FAT-PET-MRA (Doucouliagos and Stanley, 2009; Stanley, 2008).

\section{III}

\section{Meta-regressions and public policy}

The database employed consists of 63 studies of gasoline demand from the international literature, with 227 estimates of income elasticity and 343 of price elasticity being obtained. The studies cover the period from 1960 to 2013 and are from the EconLit, Jstor and ProQuest databases, among others. The studies selected were published in Spanish and English. ${ }^{7}$

The income and price elasticities of gasoline demand were divided between short- and long-run estimates. It is usual to expect sensitivity to be greater in the long run, since consumers may adjust structurally, for example, to the new relative price structure. Table 1 presents a summary of the statistics for the income and price elasticities of gasoline demand as reported in the international literature.

7 A list of the articles used in the meta-analysis is available from the authors.
All in all, the elasticities estimated in the studies generally show high volatility, with the randomeffects econometric estimates for short- and long-run income elasticity having a standard deviation-weighted average of 0.30 and 0.62 , respectively (see table 2 ). The random-effects estimates for short- and long-run price elasticity have a standard deviation-weighted average of -0.20 and -0.39 , respectively (see table 3 ). These price elasticity estimates are within the range of average price elasticities reported in the meta-analyses of Espey (1998), Hanly and others (2002) and Brons and others (2008).

The histograms and Kernel density plots for income and price elasticities show that the distributions are not symmetrical. In the case of income elasticity, the positive bias is most striking in the short-run estimates (see figure 1), while for price elasticity the bias is most evident in the long-run estimates (see figure 2).

TABLE 1

Statistics on the elasticity of gasoline demand in the international literature

\begin{tabular}{lccccc}
\hline Variable & No. of observations & Average & Standard deviation & Minimum & Maximum \\
\hline Income elasticity & & & & & \\
Long-run elasticity & 119 & 0.63 & 0.34 & 0.04 & 1.19 \\
Short-run elasticity & 108 & 0.34 & 0.19 & 0.01 & 0.94 \\
Price elasticity & & & & -1.63 & -0.32 \\
Long-run elasticity & 213 & -0.44 & 0.28 & -1.03 & 0.31 \\
Short-run elasticity & 130 & -0.21 & 0.19 & & \\
\hline
\end{tabular}

Source: Prepared by the authors. 
TABLE 2

Results from the meta-analysis of the income elasticity of gasoline demand

\begin{tabular}{|c|c|c|c|c|}
\hline \multirow{2}{*}{ Parameter } & \multicolumn{2}{|c|}{ Fixed effects } & \multicolumn{2}{|c|}{ Random effects } \\
\hline & Long run & Short run & Long run & Short run \\
\hline $\bar{\theta}$ & 0.551 & 0.268 & 0.625 & 0.303 \\
\hline$\sigma_{\theta}$ & 0.002 & 0.001 & 0.031 & 0.017 \\
\hline$\theta+1.96^{*} \sigma_{\theta}$ & 0.554 & 0.270 & 0.685 & 0.336 \\
\hline$\theta-1.96^{*} \sigma_{\theta}$ & 0.548 & 0.266 & 0.565 & 0.269 \\
\hline$Z_{\theta}=\theta / \sigma_{\theta}$ & 324.52 & 3.691 & 20.41 & 17.77 \\
\hline$P=2[1-(\Phi(|Z|))]$ & 0.000 & 0.000 & 0.000 & 0.000 \\
\hline
\end{tabular}

Source: Prepared by the authors from the results of the meta-analysis estimations.

TABLE 3

\section{Results from the meta-analysis of the price elasticity of gasoline demand}

\begin{tabular}{lccccc}
\hline \multirow{2}{*}{ Parameter } & \multicolumn{2}{c}{ Fixed effects } & & \multicolumn{2}{c}{ Random effects } \\
\cline { 2 - 3 } \cline { 5 - 6 } & Long run & Short run & & Long run & Short run \\
\hline$\theta$ & -0.131 & -0.108 & & -0.397 & -0.204 \\
$\sigma_{\theta}$ & 0.003 & 0.002 & & 0.015 & -0.021 \\
$\theta+1.96^{*} \sigma_{\theta}$ & -0.136 & -0.112 & & -0.427 & -0.245 \\
$\theta-1.96^{*} \sigma_{\theta}$ & -0.125 & -0.105 & & -0.367 & -0.163 \\
$Z_{\theta}=\theta / \sigma_{\theta}$ & 44.77 & 63.95 & & 26.05 & 9.75 \\
$P=2[1-(\Phi(|Z|))]$ & 0.000 & 0.000 & & 0.000 & 0.000 \\
\hline
\end{tabular}

Source: Prepared by the authors from the results of the meta-analysis estimations.

FIGURE 1

Distribution of estimates for the income elasticity of gasoline demand

A. Long-run income elasticity



B. Short-run income elasticity

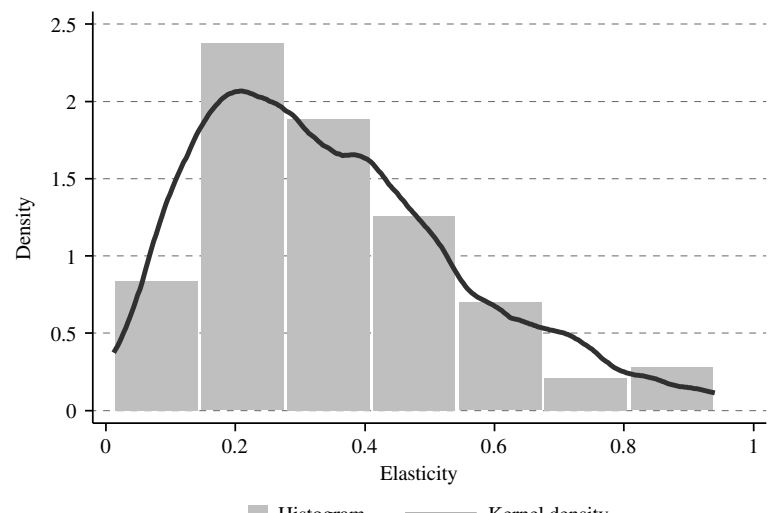

Source: Prepared by the authors. 
A. Long-run price elasticity

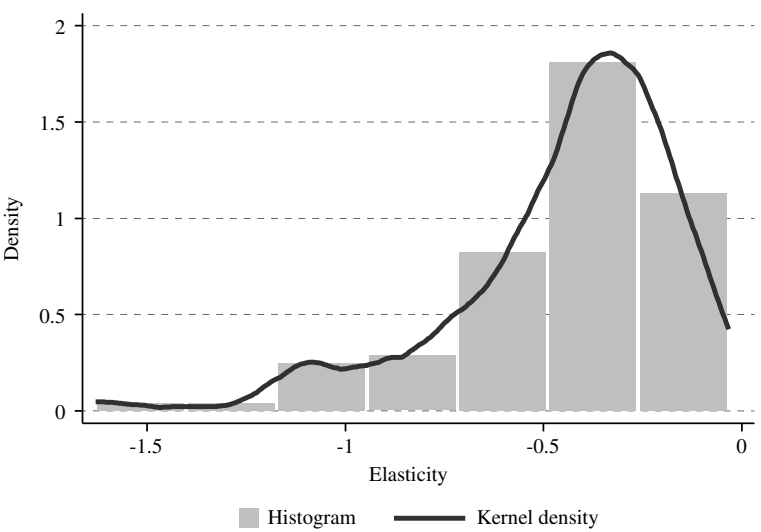

Source: Prepared by the authors.

Likewise, the asymmetry funnel plots, where the income and price elasticities are plotted along the horizontal axis and the accuracy of the estimates along the vertical axis (Abreu and Florax, 2005; Sterne and others, 2000), ${ }^{8}$ show there can be a large publication bias (see figures

${ }^{8}$ In the absence of bias, the shape of the asymmetry funnel plots depends on the variable chosen for the axes; in some cases, use is generally made of standard error, inverse standard error, variance, inverse variance, sample size and the logarithm of sample size for the vertical axis and the magnitude of the effect for the horizontal axis, with standard error probably being the best option for the vertical axis (Sterne and Egger, 2001)
B. Short-run price elasticity

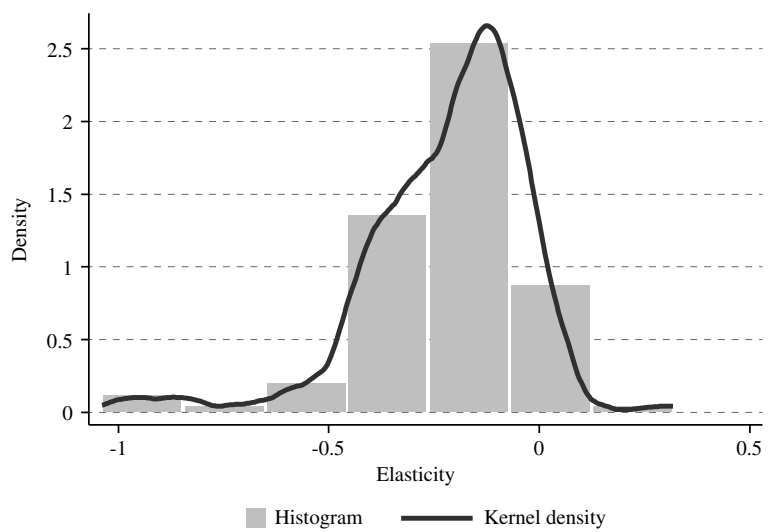

3 and 4). ${ }^{9}$ In particular, it can be seen that the distribution of the points representing the relationship between the elasticities and their respective standard deviations is not symmetrical within $95 \%$ confidence bounds. This suggests there could be a statistically significant tendency to publish studies that estimate high values for income and price elasticities.

\footnotetext{
${ }^{9}$ Publication bias has often been related to asymmetry in funnel plots; the literature reports other sources of asymmetry, however, such as selection bias, sample size heterogeneity and data irregularity, among other factors (Egger and others, 1997).
}

Funnel plots for the income and price elasticities of gasoline demand

\section{A. Long-run price elasticities}

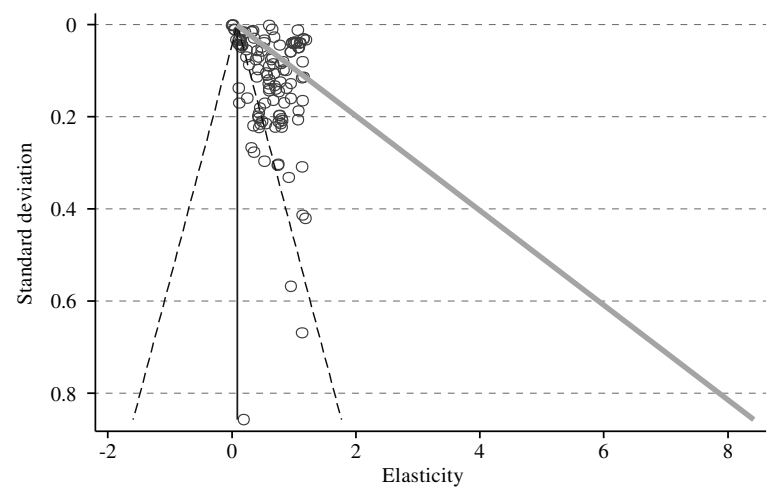

B. Short-run price elasticities

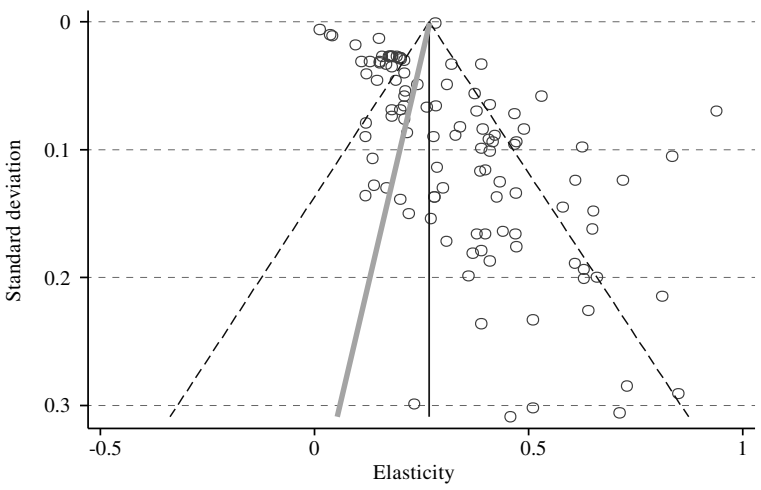

Source: Prepared by the authors.

Note: The dashed lines in the funnel plots show the $95 \%$ confidence bounds and the grey line the fit of the regression relating the gasoline price and income elasticities with their respective standard deviations. 
A. Long-run price elasticities



B. Short-run price elasticities

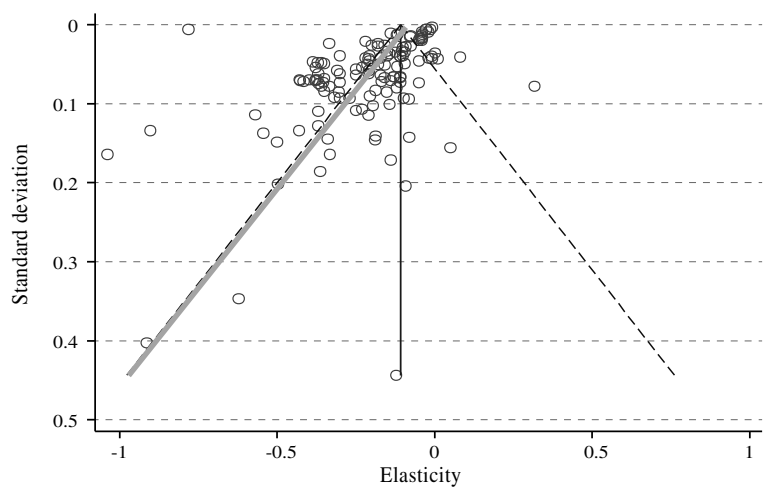

Source: Prepared by the authors.

Note: The dashed lines in the funnel plots show the $95 \%$ confidence bounds and the grey line the fit of the regression relating the gasoline price and income elasticities with their respective standard deviations.

Taken together, the available evidence thus suggests the possibility that the volatility across the effects estimated by the studies is not due exclusively to sampling errors and, accordingly, that some volatility originates in systematic factors (Van den Bergh and others, 2010). The $Q$ statistic and its $p$-value reject the null hypothesis that the distribution is homogeneous for estimates of short- and long-run income and price elasticity (see tables 4 and 5). The $p$-value of the $Q$ statistic is less than $1 \%$ of the significance level for the tests of the estimates for both long-run and short-run income elasticity (see table 4) and price elasticity (see table 5).

TABLE 4

Tests of heterogeneity for the income elasticity of gasoline demand

\begin{tabular}{lcr}
\hline Test of heterogeneity & Long run & Short run \\
\hline$Q$ & 15610.00 & 3691.00 \\
$p$-value & 0.000 & 0.000 \\
$\tau^{2}$ & 0.093 & 0.021 \\
$\tau$ & 0.306 & 0.146 \\
$I^{2}$ & $99.2 \%$ & $97.1 \%$ \\
\hline
\end{tabular}

Source: Prepared by the authors from the results of the meta-analysis estimations.

Note: $\tau^{2}$ is defined as the variance in the magnitude of the effects and indicates the variance between studies. $I^{2}$ indicates the proportion of the variation observed in the magnitude of the effects that is attributable to the heterogeneity between studies.

TABLE 5

Tests of heterogeneity for the price elasticity of gasoline demand

\begin{tabular}{lrr}
\hline Test of heterogeneity & Long run & Short run \\
\hline$Q$ & 3341.34 & 15465.27 \\
$p$-value & 0.000 & 0.000 \\
$\tau^{2}$ & 0.031 & 0.051 \\
$\tau$ & 0.175 & 0.225 \\
$I^{2}$ & $93.7 \%$ & $99.2 \%$
\end{tabular}

Source: Prepared by the authors from the results of the meta-analysis estimations.

Note: $\tau^{2}$ is defined as the variance in the magnitude of the effects and indicates the variance between studies. $I^{2}$ indicates the proportion of the variation observed in the magnitude of the effects that is attributable to the heterogeneity between studies. 
The $I^{2}$ statistic indicates that over $90 \%$ of the observed variation in the magnitude of the effects is attributable to the heterogeneity between the studies, meaning that the variation in the income and price elasticities of gasoline demand is almost wholly due to the differences in the studies included in the meta-analysis. This suggests, then, that meta-regression techniques should be applied to identify the variability ratios for elasticity (see table 8).

On the basis of the maximum likelihood ratio test, the equation (6) estimates show that the null hypothesis of homogeneity in the estimates is rejected (see table 6). This suggests there is substantial heterogeneity in the income and price elasticities and that the mixed-effects model is therefore appropriate. The findings show a positive bias for long-run income elasticity and a negative one for short-run elasticity, although this short-run bias is not statistically significant. The findings for short- and longrun price elasticity (see table 6) indicate a statistically significant negative bias; this is consistent with what is reported in the asymmetry funnel plots. Likewise, the results of the equation (6) estimates show that the effect or the real elasticity is statistically different from zero in all cases (the 1/SE coefficient is statistically significant at $1 \%$ ). In other words, income and price elasticities are factors affecting the path of gasoline consumption in the short and long run.

The estimates from Heckman's meta-regression (equation (7)) show that the short- and long-run income elasticities are 0.26 and 0.46 , respectively, once publication bias is corrected for. In turn, the short- and long-run price elasticities are -0.10 and -0.31 , respectively, including the bias correction (see table 7). The likelihood ratio tests reject the null hypothesis that volatility is only a consequence of sampling error, which means that it is appropiate to use a mixed-effects model.

The international literature on gasoline demand suggests that a number of factors, besides the difference between short- and long-run elasticities already discussed, affect the volatility of estimations of the income and price elasticities of this demand. In principle, the following factors can be considered:

TABLE 6

Publication bias test

\begin{tabular}{|c|c|c|c|c|}
\hline \multirow{2}{*}{ Dependent variable: $t$-statistic } & \multicolumn{2}{|c|}{ Income elasticity } & \multicolumn{2}{|c|}{ Price elasticity } \\
\hline & Long run & Short run & Long run & Short run \\
\hline $\begin{array}{l}\text { Constant } \\
(1 / S E)\end{array}$ & $\begin{array}{l}0.767 \\
(1.039) \\
0.456^{* * *} \\
(0.019)\end{array}$ & $\begin{array}{l}-0.697 \\
(0.579) \\
0.270^{* * *} \\
(0.005)\end{array}$ & $\begin{array}{l}-1.500 * * * \\
(0.268) \\
-0.234 * * * \\
(0.020)\end{array}$ & $\begin{array}{l}-1.973^{*} \\
(1.171) \\
-0.086^{* * *} \\
(0.022)\end{array}$ \\
\hline $\begin{array}{l}\text { No. of observations } \\
\text { Likelihood ratio test }\end{array}$ & $\begin{array}{l}119 \\
561.15^{* * * *}\end{array}$ & $\begin{array}{rl} & 108 \\
2 & 185.27 * * *\end{array}$ & $\begin{array}{l}213 \\
130.07 * * *\end{array}$ & $\begin{array}{l}130 \\
14.47 * * *\end{array}$ \\
\hline
\end{tabular}

Source: Prepared by the authors from the estimates of the mixed-effects model.

Note: The values in parentheses are the standard errors. The asterisks $* * *, * *$ and $*$ indicate significance at $1 \%, 5 \%$ and $10 \%$, respectively. The test of joint significance is carried out using $\chi^{2}$. SE is the standard error.

TABLE 7

Income and price elasticity of gasoline demand corrected for bias

\begin{tabular}{|c|c|c|c|c|}
\hline \multirow{2}{*}{ Dependent variable: t-statistic } & \multicolumn{2}{|c|}{ Income elasticity } & \multicolumn{2}{|c|}{ Price elasticity } \\
\hline & Long run & Short run & Long run & Short run \\
\hline Corrected elasticity (1/SE) & $\begin{array}{l}0.461 * * * \\
(0.017)\end{array}$ & $\begin{array}{l}0.267 * * * \\
(0.006)\end{array}$ & $\begin{array}{l}-0.314 * * * \\
(0.014)\end{array}$ & $\begin{array}{l}-0.104 * * * \\
(0.018)\end{array}$ \\
\hline$S E$ & $\begin{array}{c}4.493 \\
(5.178)\end{array}$ & $\begin{array}{c}4.646 \\
(4.315)\end{array}$ & $\begin{array}{l}-1.004^{* *} \\
(0.520)\end{array}$ & $\begin{array}{r}-10.978 \\
(9.828)\end{array}$ \\
\hline No. of observations & 119 & 108 & 213 & 130 \\
\hline Likelihood ratio test $\left(\chi^{2}\right)$ & $711.50 * * *$ & $2323.50 * * *$ & $497.31 * * *$ & $36.06^{* * *}$ \\
\hline
\end{tabular}

Source: Prepared by the authors from the estimates of the mixed-effects model.

Note: The values in parentheses are the standard errors. The asterisks ***, ** and * indicate rejection at the $1 \%, 5 \%$ and $10 \%$ significance level, respectively. The test of joint significance is carried out using $\chi^{2} . S E$ is the standard error. 
TABLE 8

Description of the variables included in the meta-regression

\begin{tabular}{ll}
\hline Variable & Description \\
\hline -statistic & Value of the $t$-statistic for the estimates reported in each study. \\
$1 / S E$ & Variable measuring the accuracy of the estimate as the inverse standard deviation of the estimated elasticity. \\
Qualitative variable taking the value 1 if the included study was carried out for an oEcD country (city, state or \\
region) and 0 otherwise. \\
Qualitative variable taking the value 1 if the included study was carried out for a Latin American country \\
(city, state or region) and 0 otherwise. \\
Vehicle fleet & $\begin{array}{l}\text { Dummy variable taking the value } 1 \text { if the model reported in the study includes the vehicle fleet as an } \\
\text { explanatory variable and } 0 \text { otherwise. } \\
\text { Dummy variable taking the value } 1 \text { if the model reported in the study includes the price of another fuel as an } \\
\text { explanatory variable and } 0 \text { otherwise. }\end{array}$ \\
Cross-section & $\begin{array}{l}\text { Dummy variable taking the value } 1 \text { if the model information is cross-sectional and } 0 \text { otherwise. } \\
\text { National }\end{array}$ \\
Dynamic & Dummy variable taking the value 1 if the included study is carried out nationwide and 0 otherwise.
\end{tabular}

Source: Prepared by the authors.

Note: OECD means all member countries of the Organization for Economic Cooperation and Development except Chile and Mexico. $S E$ is the standard error.

(i) The magnitudes of the income and price elasticities of gasoline demand differ by country or region (Pock, 2007; Bentzen, 1994; Sterner, Dahl and Franzén, 1992). Accordingly, the income elasticity of gasoline demand is expected to be higher in middle-income countries than in developed ones and the price elasticity lower in developing countries than in developed ones (Brons and others, 2008; Havranek and others, 2012). The difference in the price elasticities of gasoline demand may be due to the greater availability of substitutes for private transport in developed countries, among other factors.

(ii) The magnitudes of income and price elasticities change depending on the characteristics and evolution of the vehicle fleet (Espey, 1998; Brons and others, 2008). In other words, gasoline demand can be derived from the characteristics of the vehicle fleet (such as fuel expenditure per kilometre) and the number of kilometres driven (Brons and others, 2008):

$$
G A S_{i t}=\sum_{i=1}^{i=n} K M_{i t} C A R_{i t}
$$

where $G A S_{i t}$ represents total gasoline consumption, $K M_{i t}$ are the kilometres covered by the vehicle fleet, $C A R_{i t}$ is this fleet, $n$ is the total number of vehicles and subscript $i$ and $t$ represent vehicles and time, respectively. The economic literature also establishes that demand for automobiles is a function of the evolution of spending or income and the relative prices of vehicles, among other factors. Thus, including the vehicle fleet in the gasoline demand equation means that the effect of income on this demand has an additional channel represented by the vehicle fleet. Accordingly, including automobile ownership and vehicle fleet characteristics (efficiency) gives rise to more inelastic estimates of demand relative to income in the short run, and possibly the long run too (Espey, 1998).

(iii) The magnitudes of the price elasticities of gasoline demand change when the prices of substitute fuels are included in the specification of this demand, such as ethanol or biodiesel (Dahl, 1992), ${ }^{10}$ or when the price of public transport is included. For example, Goodwin (1992) shows that increasing the price of public transport reduces its use, so that there are channels of transmission with the level of private transport usage.

(iv) The magnitudes of the income and price elasticities differ depending on the type of data and the estimation methods applied (Graham and Glaister, 2002; Espey, 1998). In other words, it is common for panel data or cross-sectional estimates to translate into lower coefficients than those estimated using time series.

\footnotetext{
10 Consideration was given to including natural gas in the analysis of gasoline demand because of its importance as a substitute for transportation purposes in some Latin American countries, but there were not enough studies available for these to be incorporated into the meta-regression.
} 
Tables 9 and 10 report the results for the metaregression with different estimation methods, where the factors determining the heterogeneity in the magnitude of the long- and short-run income and price elasticities of gasoline demand are identified.

The estimations for income and price elasticities using the fixed, random and mixed Heckman-type effects methods are presented in table 11. The evidence available generally suggests that the mixed-effects model is the most appropriate. ${ }^{11}$

${ }^{11}$ For example, Havranek and others (2012) show that substantially lower price elasticities are obtained with the mixed-effects model than in other price meta-analyses (Brons and others, 2008; Espey, 1998).
Thus, the following can be inferred from the results obtained:

- The magnitudes of the short- and long-run income and price elasticities of gasoline demand differ by country or region (Pock, 2007; Bentzen, 1994; Sterner, Dahl and Franzén, 1992). Long-run income elasticity is lower (0.55) for the OECD countries, excluding Chile and Mexico, than for Latin America (0.69), while long-run price elasticities are higher in absolute terms in the OECD countries (-0.41), excluding Chile and Mexico, than in Latin America $(-0.31)$ (see table 12). Short-run income and price elasticities, on the other hand, are similar in the different regions.

TABLE 9

Meta-regression: determinants of the income elasticity of gasoline demand

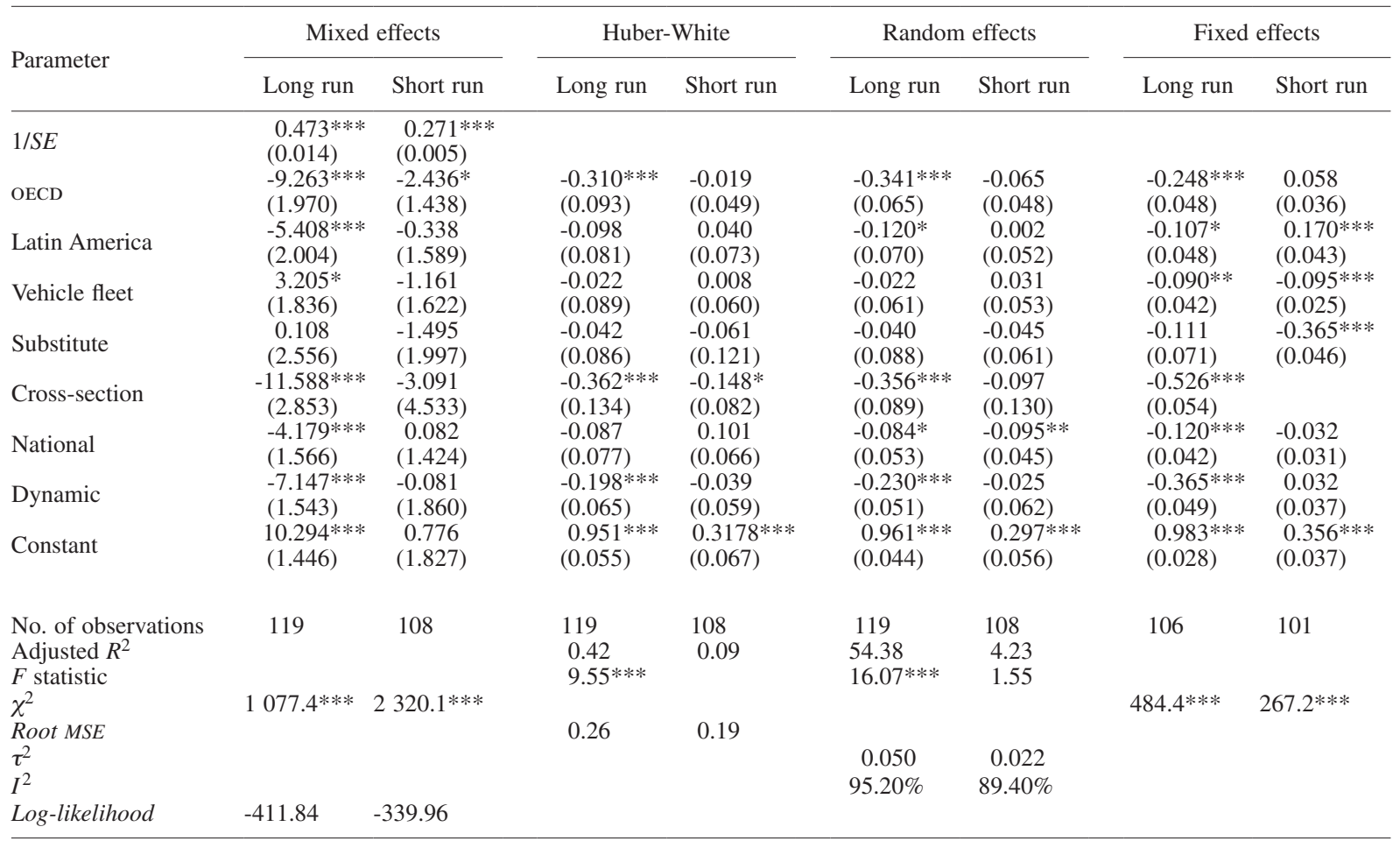

Source: Prepared by the authors.

Note: The values in parentheses are the standard errors. The asterisks $* * *, * *$ and $*$ indicate significance at $1 \%, 5 \%$ and $10 \%$, respectively. Adjusted $R^{2}$ is the adjusted coefficient of determination of the meta-regression and measures the proportion of the variance between studies that is explained by the variables included in the model. The $F$ statistic proves the null hypothesis that the variables included in the model are jointly equal to zero $\left(\beta_{1}=\beta_{2}=\ldots=\beta_{k}=0\right)$, in the case of the random-effects and Huber-White models, while for the fixed- and mixedeffects models the joint significance test is carried out using $\chi^{2} \cdot \tau^{2}$ estimates the variance between studies for the random-effects model. $I^{2}$ indicates the proportion of the variation observed in the magnitude of the effects that is attributable to heterogeneity between studies. Root MSE is the square root of the mean quadratic error. OECD means all member countries of the Organization for Economic Cooperation and Development except Chile and Mexico. SE is the standard error. 
TABLE 10

Meta-regression: determinants of the price elasticity of gasoline demand

\begin{tabular}{|c|c|c|c|c|c|c|c|c|}
\hline \multirow{2}{*}{ Parameter } & \multicolumn{2}{|c|}{ Mixed effects } & \multicolumn{2}{|c|}{ Huber-White } & \multicolumn{2}{|c|}{ Random effects } & \multicolumn{2}{|c|}{ Fixed effects } \\
\hline & Long run & Short run & Long run & Short run & Long run & Short run & Long run & Short run \\
\hline $1 / S E$ & $\begin{array}{l}-0.324 * * * \\
(0.021)\end{array}$ & $\begin{array}{l}-0.087 * * * \\
(0.022)\end{array}$ & & & & & & \\
\hline OECD & $\begin{array}{l}-1.382 * * * \\
(0.443)\end{array}$ & $\begin{array}{l}-2.548 \\
(2.359)\end{array}$ & $\begin{array}{l}-0.132 \\
(0.092)\end{array}$ & $\begin{array}{l}-0.031 \\
(0.039)\end{array}$ & $\begin{array}{l}-0.102 * * \\
(0.045)\end{array}$ & $\begin{array}{l}-0.071 * * \\
(0.034)\end{array}$ & $\begin{array}{l}-0.145 * * * \\
(0.035)\end{array}$ & $\begin{array}{l}-0.064 * * * \\
(0.018)\end{array}$ \\
\hline Latin America & $\begin{array}{l}-1.426 * * \\
(0.575)\end{array}$ & $\begin{array}{l}-3.109 \\
(2.628)\end{array}$ & $\begin{array}{l}-0.151 * \\
(0.089)\end{array}$ & $\begin{array}{l}-0.022 \\
(0.058)\end{array}$ & $\begin{array}{l}-0.159 * * \\
(0.064)\end{array}$ & $\begin{array}{l}-0.059 \\
(0.039)\end{array}$ & $\begin{array}{c}0.035 \\
(0.041)\end{array}$ & $\begin{array}{l}-0.008 \\
(0.024)\end{array}$ \\
\hline Vehicle fleet & $\begin{array}{c}0.723 * \\
(0.452)\end{array}$ & $\begin{array}{c}2.206 \\
(2.603)\end{array}$ & $\begin{array}{c}0.089 \\
(0.064)\end{array}$ & $\begin{array}{c}0.022 \\
(0.058)\end{array}$ & $\begin{array}{l}-0.062 \\
(0.045)\end{array}$ & $\begin{array}{c}0.037 \\
(0.038)\end{array}$ & $\begin{array}{c}0.006 \\
(0.035)\end{array}$ & $\begin{array}{c}0.016 \\
(0.017)\end{array}$ \\
\hline Substitute & $\begin{array}{l}-0.380 \\
(0.397)\end{array}$ & $\begin{array}{l}-3.852 \\
(3.188)\end{array}$ & $\begin{array}{l}-0.123 * * \\
(0.054)\end{array}$ & $\begin{array}{l}-0.124 \\
(0.079)\end{array}$ & $\begin{array}{l}-0.112 * * \\
(0.046)\end{array}$ & $\begin{array}{l}-0.109 * * \\
(0.047)\end{array}$ & $\begin{array}{l}-0.131 * * * \\
(0.028)\end{array}$ & $\begin{array}{l}-0.251 * * * \\
(0.072)\end{array}$ \\
\hline Cross-section & $\begin{array}{l}-1.051 \\
(0.749)\end{array}$ & $\begin{array}{l}-2.232 \\
(5.736\end{array}$ & $\begin{array}{l}-0.320 * * * \\
(0.095)\end{array}$ & $\begin{array}{l}-0.319 * * * \\
(0.073)\end{array}$ & $\begin{array}{l}-0.252 * * * \\
(0.088)\end{array}$ & $\begin{array}{l}-0.289 * * * \\
(0.088)\end{array}$ & $\begin{array}{l}-0.138 * * \\
(0.065)\end{array}$ & $\begin{array}{l}-0.372 * * * \\
(0.087)\end{array}$ \\
\hline National & $\begin{array}{l}0.829 * * \\
(0.415)\end{array}$ & $\begin{array}{c}3.585 \\
(2.324)\end{array}$ & $\begin{array}{c}0.059 \\
(0.096)\end{array}$ & $\begin{array}{c}0.023 \\
(0.041)\end{array}$ & $\begin{array}{c}0.071 * \\
(0.042)\end{array}$ & $\begin{array}{c}0.033 \\
(0.034)\end{array}$ & $\begin{array}{l}0.167 * * * \\
(0.031)\end{array}$ & $\begin{array}{l}-0.047 * * \\
(0.019)\end{array}$ \\
\hline Dynamic & $\begin{array}{l}-0.647 * \\
(0.355)\end{array}$ & $\begin{array}{l}-1.665 \\
(3.011)\end{array}$ & $\begin{array}{l}-0.121 \\
(0.091)\end{array}$ & $\begin{array}{l}-0.025 \\
(0.067)\end{array}$ & $\begin{array}{l}-0.044 \\
(0.038)\end{array}$ & $\begin{array}{l}-0.031 \\
(0.043)\end{array}$ & $\begin{array}{l}0.180 * * * \\
(0.023)\end{array}$ & $\begin{array}{l}-0.056^{* * *} \\
(0.024)\end{array}$ \\
\hline Constant & $\begin{array}{l}-0.158 \\
(0.430)\end{array}$ & $\begin{array}{l}-0.854 \\
(3.056)\end{array}$ & $\begin{array}{l}-0.321 * * * \\
(0.056)\end{array}$ & $\begin{array}{l}-0.169 * * * \\
(0.059)\end{array}$ & $\begin{array}{l}-0.334 * * * \\
(0.040)\end{array}$ & $\begin{array}{l}-0.127 * * * \\
(0.043)\end{array}$ & $\begin{array}{l}-0.391 * * * \\
(0.247)\end{array}$ & $\begin{array}{l}-0.048 * * \\
(0.025)\end{array}$ \\
\hline $\begin{array}{l}\text { No. of observations } \\
\text { Adjusted } R^{2} \\
F \text { statistic }\end{array}$ & 213 & 130 & $\begin{array}{l}213 \\
0.16 \\
16.47^{* * *}\end{array}$ & $\begin{array}{l}130 \\
0.16\end{array}$ & $\begin{array}{l}213 \\
9.91 \\
4.23 * * *\end{array}$ & $\begin{array}{l}130 \\
23.67 \\
4.64 * * *\end{array}$ & 202 & 126 \\
\hline $\begin{array}{l}\chi^{2} \\
\text { Root MSE } \\
\mathrm{t}^{2} \\
I^{2}\end{array}$ & $275.44 * * *$ & $27.2 * * *$ & 0.26 & 0.18 & $\begin{array}{c}0.041 \\
90.18 \%\end{array}$ & $\begin{array}{c}0.016 \\
96.31 \%\end{array}$ & $135.8 * * *$ & $60.8 * * *$ \\
\hline Log-likelihood & -414.4 & -488.1 & & & & & & \\
\hline
\end{tabular}

Source: Prepared by the authors.

Note: The values in parentheses are the standard errors. The asterisks ***, ** and $*$ indicate significance at $1 \%, 5 \%$ and $10 \%$, respectively. Adjusted $R^{2}$ is the adjusted coefficient of determination of the meta-regression and measures the proportion of the variance between studies that is explained by the variables included in the model. The $F$ statistic proves the null hypothesis that the variables included in the model are jointly equal to zero $\left(\beta_{1}=\beta_{2}=\ldots=\beta_{k}=0\right)$, in the case of the random-effects and Huber-White models, while for the fixed-and mixedeffects models the joint significance test is carried out using $\chi^{2} \cdot \tau^{2}$ estimates the variance between studies for the random-effects model. $I^{2}$ indicates the proportion of the variation observed in the magnitude of the effects that is attributable to heterogeneity between studies. Root $M S E$ is the square root of the mean quadratic error. OECD means all member countries of the Organization for Economic Cooperation and Development except Chile and Mexico. SE is the standard error.

TABLE 11

Summary of estimates of the income and price elasticities of gasoline demand

\begin{tabular}{|c|c|c|c|c|}
\hline \multirow{2}{*}{ Model } & \multicolumn{2}{|c|}{ Income elasticity } & \multicolumn{2}{|c|}{ Price elasticity } \\
\hline & Long run & Short run & Long run & Short run \\
\hline Fixed effects & $\begin{array}{l}0.551 * * * \\
(0.002)\end{array}$ & $\begin{array}{l}0.268 * * * \\
(0.001)\end{array}$ & $\begin{array}{l}-0.131 * * * \\
(0.003)\end{array}$ & $\begin{array}{l}-0.108 * * * \\
(0.002)\end{array}$ \\
\hline Random effects & $\begin{array}{l}0.625 * * * \\
(0.031)\end{array}$ & $\begin{array}{l}0.303 * * * \\
(0.017)\end{array}$ & $\begin{array}{l}-0.397 * * * \\
(0.015)\end{array}$ & $\begin{array}{l}-0.204 * * * \\
(0.021)\end{array}$ \\
\hline Mixed effects & $\begin{array}{l}0.461 * * * \\
(0.017)\end{array}$ & $\begin{array}{l}0.267 * * * \\
(0.006)\end{array}$ & $\begin{array}{l}-0.314 * * * \\
(0.014)\end{array}$ & $\begin{array}{l}-0.104 * * * \\
(0.018)\end{array}$ \\
\hline
\end{tabular}

Source: Prepared by the authors.

Note: The values in parentheses are the standard errors. The asterisks $* * *, * *$ and $*$ indicate significance at $1 \%, 5 \%$ and $10 \%$, respectively. 
TABLE 12

Income and price elasticity of gasoline demand by region

\begin{tabular}{cccc}
\hline & OECD countries & Rest of world & Latin America \\
\hline Income elasticity & 0.55 & 0.79 & 0.69 \\
Long-run elasticity & 0.24 & 0.29 & 0.26 \\
$\begin{array}{c}\text { Short-run elasticity } \\
\text { Price elasticity }\end{array}$ & -0.41 & -0.37 & -0.31 \\
Long-run elasticity & -0.22 & -0.20 & -0.17 \\
Short-run elasticity & & & \\
\hline
\end{tabular}

Source: Prepared by the authors.

Note: Elasticity weighted by the standard deviation was estimated using the random-effects model. In all cases, the $Q$ test rejects the null hypothesis that the estimates are homogeneous. The $I^{2}$ statistic indicates that the proportion of the variation in the magnitude of the effects that can be attributed to heterogeneity between studies is greater than $85 \%$ for both the long-run and the short-run income and price elasticities. OECD means all member countries of the Organization for Economic Cooperation and Development except Chile and Mexico.

- The magnitudes of the income and price elasticities change depending on the characteristics and evolution of the vehicle fleet. Thus, long-run income and price elasticity is lower in studies that include the vehicle fleet than in those where this explanatory variable is not included (see table 13). In the short run, the capacity to respond to income and price changes is found to be smaller. The reduction in the income elasticity of gasoline demand (when the vehicle fleet is included as an explanatory variable) is partially a consequence of the strong collinearity between the paths followed by income and the vehicle fleet. Changes in price elasticities also suggest the presence of complex adjustment processes among consumers.

- The magnitudes of the price elasticities of gasoline demand change when the prices of substitute fuels such as ethanol or biodiesel are included in the fuel demand specification (see table 14). As might be expected, the existence of substitute fuels means consumer demand has a greater capacity to respond to price changes in both the long and short run.

- The magnitudes of the income and price elasticities also differ depending on the estimation methods applied (Graham and Glaister, 2002; Espey, 1998). Thus, higher income elasticities are obtained when the meta-analysis is carried out exclusively with studies where the maximum likelihood method is applied than when it includes only studies using ordinary least squares or the generalized method of moments as estimation methods (see table 15). Price elasticities also differ depending on the estimation method employed, something that is consistent with the studies of Espey (1998) and Havranek and others (2012).

\begin{tabular}{ccc}
\hline & $\begin{array}{c}\text { Elasticity when the vehicle } \\
\text { fleet is taken into account }\end{array}$ & $\begin{array}{c}\text { Elasticity when the vehicle } \\
\text { fleet is not taken into account }\end{array}$ \\
\hline Income elasticity & 0.49 & 0.67 \\
Long-run elasticity & 0.29 & 0.30 \\
Short-run elasticity & -0.35 & -0.40 \\
Price elasticity & -0.16 & -0.21 \\
Long-run elasticity & & \\
Short-run elasticity
\end{tabular}

Source: Prepared by the authors.

Note: Elasticity weighted by the standard deviation was estimated using the random-effects model. In all cases, the $Q$ test rejects the null hypothesis that the estimates are homogeneous. The $I^{2}$ statistic indicates that the proportion of the variation in the magnitude of the effects that can be attributed to heterogeneity between studies is greater than $85 \%$ for both the long-run and short-run income and price elasticities. 
Income and price elasticity of gasoline demand when the price of substitutes is taken into account

\begin{tabular}{|c|c|c|}
\hline & $\begin{array}{c}\text { Elasticity when the price of } \\
\text { substitutes is taken into account }\end{array}$ & $\begin{array}{l}\text { Elasticity when the price of } \\
\text { substitutes is not taken into account }\end{array}$ \\
\hline \multicolumn{3}{|l|}{ Income elasticity } \\
\hline Long-run elasticity & 0.58 & 0.62 \\
\hline Short-run elasticity & 0.23 & 0.31 \\
\hline \multicolumn{3}{|l|}{ Price elasticity } \\
\hline Long-run elasticity & -0.48 & -0.38 \\
\hline Short-run elasticity & -0.32 & -0.16 \\
\hline
\end{tabular}

Source: Prepared by the authors.

Note: Elasticity weighted by the standard deviation was estimated using the random-effects model. In all cases, the $Q$ test rejects the null hypothesis that the estimates are homogeneous. The $I^{2}$ statistic indicates that the proportion of the variation in the magnitude of the effects that can be attributed to heterogeneity between studies is greater than $85 \%$ for both the long-run and short-run income and price elasticities.

TABLE 15

Income and price elasticity of gasoline demand by estimation method

\begin{tabular}{cccc}
\hline & Ordinary least squares & $\begin{array}{c}\text { Maximum likelihood } \\
\text { Generalized method } \\
\text { of moments }\end{array}$ \\
\hline Income elasticity & 0.62 & 0.67 & 0.27 \\
Long-run elasticity & 0.33 & 0.49 & 0.21 \\
$\begin{array}{c}\text { Short-run elasticity } \\
\text { Price elasticity }\end{array}$ & -0.46 & -0.20 & -0.11 \\
Long-run elasticity & -0.20 & -0.08 & -0.32 \\
\hline Short-run elasticity & & & \\
\hline
\end{tabular}

Source: Prepared by the authors.

Note: Elasticity weighted by the standard deviation was estimated using the random-effects model. In all cases, the $Q$ test rejects the null hypothesis that the estimates are homogeneous. The $I^{2}$ statistic indicates that the proportion of the variation in the magnitude of the effects that can be attributed to heterogeneity between studies is greater than $85 \%$ for both the long-run and short-run income and price elasticities.

Some public policy conclusions can be drawn from the results of the meta-analysis. Gasoline consumption is associated with a variety of negative externalities, such as costs deriving from vehicle traffic, air pollution and climate change (Cnossen, 2005; Kayser, 2000). There are also collateral effects whose incidence is very heterogeneous, such as changes in property values related to air pollution and noise (Verhoef, 1994; Schipper, 1996). The magnitude of these costs in Latin America is certainly significant and will probably carry on rising if the current development style is maintained (Parry and Strand, 2010; Hernández and Antón, 2013). These negative effects are concentrated in urban areas, which is a cause for concern considering that about $80 \%$ of the Latin American population currently lives in these and the region's urban population is expected to rise to 640.1 million by $2050 .{ }^{12}$

Thus, in Latin America, with its rapid growth in urban living and motor vehicle use, the standards set for

12 According to the population projections of the Latin American and Caribbean Demographic Centre (CELADE)-Population Division of ECLAC. the concentration of air pollutants are often exceeded. This situation is considered highly hazardous to public health, since there is evidence that a rise of $10 \mu \mathrm{g} / \mathrm{m}^{3}$ (micrograms per cubic metre) of particulate matter (PM10) is associated with an increase in morbidity and mortality from respiratory diseases (Cropper and others, 1997; Lozano, 2004).

Thus, the income elasticity of mean gasoline demand derived from the meta-analysis suggests that, under current circumstances, continuous economic growth will translate into a substantial rise in gasoline consumption with all the resulting negative collateral effects, mainly in urban areas. Even more, the evidence of the metaanalysis shows that both income elasticities are higher in Latin America than in developed countries, taking the OECD countries other than Chile and Mexico as the sample. This reflects the fact that the economic growth style or its current phase in the region is closely bound up with gasoline consumption, whereas the developed countries have succeeded in decoupling the relationship somewhat. The evidence from the meta-analysis also shows that income elasticities are altered by the inclusion of the vehicle fleet. Part of this change in the income 
elasticity of gasoline demand can be explained by the close link between income and vehicle demand, which induces a degree of multicolinearity into the estimation. Thus, the current development style in Latin America is consolidating a growing demand for private transport that is being reflected by rapid growth in the vehicle fleet. All this suggests that, under current circumstances, gasoline consumption and the negative externalities caused by transport are very likely to intensify in the region's urban areas.

Short-run elasticities are lower than long-run ones, which suggests that there are adjustment and information costs delaying economic agents' response to rising gasoline prices. There is even international evidence that consumers respond asymmetrically to price changes (Gately, 1992).

The price elasticity of gasoline demand yielded by the meta-analysis for Latin America suggests that a tax on gasoline consumption has a negative effect, but that this is small and unlikely to be enough to control rising consumption when economic growth is rapid. The low price elasticity of gasoline demand is partially due to the fact that there are fewer suitable substitutes for private transport in the region than in the OECD countries. For consumption to become more sensitive to relative prices, then, real alternatives to private transport need to be pursued.

There is now a wide range of economic instruments and regulations that are applied to control or induce the path of gasoline demand. For example, there are taxes on things such as car registration, the use of road infrastructure, the externalities caused by transport (air pollution, noise, accidents or congestion), gasoline itself, lane use and imported cars (depending on characteristics or engine capacity), besides systems of tradable permits and additional financial costs reflected in the price of insurance or parking charges (Brons and others, 2008; Markandya and Shibli, 1995). ${ }^{13}$ There have also been strong moves towards making transport regulations stricter, including rules on efficiency (kilometres per litre of gasoline) and noise, and restrictions on vehicle use on particular days or in particular zones (European Commission, 2014; Alcaldía Mayor de Bogotá, 2000).

The application of fiscal policies to gasoline consumption is, in any event, an important instrument for

\footnotetext{
13 Systems involving economic instruments have even been put in place to restrict car use in certain zones, as in the city of Boston (Gómez-Ibáñez and Futh, 1980).
}

controlling or inducing a specific behaviour. For example, the environmental tax take in the OECD countries represents about two percentage points of GDP, although there is considerable variation between countries. Conversely, in Latin America, and particularly in hydrocarbonproducing countries, there is still a tendency to subsidize petroleum-derived products.

Taken together, the evidence presented suggests that a strategy to control gasoline consumption should include at least the following:

(i) Higher gasoline prices, considering that prices are often subsidized at present or do not incorporate the externalities caused by gasoline consumption (Cnossen, 2005; Hernández and Antón, 2013).

(ii) The application of a set of regulations that affect gasoline consumption ${ }^{14}$ and are consistent with the pricing strategy and regulations. These might include measures such as special licences, traffic zoning, congestion charging, vehicle restrictions in particular urban zones, improvements to public transport and measures applying only to private vehicles that affect congestion (Van den Bergh and others, 2010).

(iii) Explicit strategies to increase the price elasticity of gasoline demand. This means developing a modern, efficient and safe road infrastructure that prioritizes public transport. The development of this infrastructure can also have positive effects on regional income (Rietveld, 1994; Verhoef, 1994).

(iv) The development of specific mobility strategies, including the construction of cycle lanes, pedestrian areas and other forms of transport, and the development of a densification and urban land use strategy that optimizes the use of mass transport and reduces travel distances. For example, Phillips and Goss (1995) show in a meta-analysis that, when public services are controlled for, raising taxes in a given metropolitan area reduces economic activity. This means that different economic instruments can be effective in reshaping urban areas and thence mobility needs.

(v) The realization that public policies do not induce automatic adjustments and that there will therefore be a time lag before their full effects are felt, as is shown by the differences between short- and long-run income and price elasticities.

\footnotetext{
${ }^{14}$ For example, Goldberg (1998) shows that the system of efficiency standards regulation in the United States, known as corporate average fuel economy (CAFE), can complement a pricing strategy.
} 


\section{IV}

\section{Conclusions and general comments}

The international evidence synthesized in this study confirms that estimates of the income and price elasticities of gasoline demand are very diverse and volatile, while the asymmetrical behaviour of their distribution suggests publication bias. The estimates and econometric tests conducted (FAT-PET-MRA) show that the null hypothesis of differences in the estimates being a consequence of sampling error alone is rejected, that there is genuine heterogeneity and that, consequently, a mixed-effects model needs to be used in the meta-regression.

The meta-regression estimates indicate that the income and price elasticities of gasoline demand are statistically significant, i.e., the mean of the short- and long-run elasticities is different from zero even after correcting for publication bias. They also indicate that there is a positive bias in long-run income elasticity and a negative bias in short- and long-run price elasticities. Thus, the meta-regression estimates for the whole sample of studies suggest average income elasticities of 0.26 for the short run and 0.46 for the long run. These estimates also suggest short- and long-run price elasticities of -0.10 and -0.31 , respectively.

The volatility of the estimates is due, of course, to a whole range of factors. The meta-regression indicates that the income elasticities estimated change depending on a countries' development level, the vehicle fleet, the type of data used, the estimation zone and the dynamic structure of the models, among other factors. Meanwhile, the evidence for price elasticities shows that there is also an asymmetrical volatility originating both in publication biases and in other systematic factors. The meta-regression shows that the price elasticities of gasoline demand vary with the region or vehicle fleet, among other things.

This points up the fact that the average income elasticity of gasoline demand is higher in Latin America than in the OECD countries, while average price elasticity is lower in the region than in the OECD. This is the result of a complex matrix of factors and interactions. Nonetheless, it could be argued that high income elasticity and low price elasticity reflect the same general phenomenon: the style and phase of economic development in Latin America, with relative prices and a configuration of transport modes and options that do not provide a reasonable substitute for private transport.
What is seen in the region, adjusting for prices, is that economic growth is shaping new groups of consumers who are gradually abandoning public transport for private transport, partly because public transport does not meet their mobility requirements in terms of safety, comfort and travel times.

The consequences of this increase in gasoline consumption have been showing up, especially in urban areas, in the form of acute negative externalities, such as air pollution, noise, road accidents, congestion and climate change. This makes it advisable to apply a tax that internalizes the costs resulting from gasoline consumption. However, the price elasticities inferred for Latin America suggest that the response to higher prices is insensitive, so that consumption is very likely to go on rising in a context of strong economic growth. In any event, low price elasticities can be taken advantage of for revenue-raising purposes. Thus, a strategy to help control demand for gasoline also requires a strategy of relative pricing or taxes that reflect the real cost of consuming it, regulatory measures such as standards for emissions per kilometre travelled, limitations on vehicle travel and an adequate public transport infrastructure, combined with cycle lanes and pedestrian-only areas. Furthermore, urban development styles more generally need to be consistent with these measures. Thus, the creation of efficient public mass transit systems, improvements in fuel quality and performance and technological progress in the automotive industry can not only help to reduce emissions, but can yield health benefits, reduce accidents and cut travel times.

Subsidizing gasoline is a common policy in many countries of Latin America; where environmental goals are concerned, however, it creates a perverse incentive by stimulating consumption of a good that induces a negative externality. Indeed, not only should subsidies for fuel be dismantled, but the social costs of consuming it should be reflected in its pricing. Abolishing these subsidies will increase not just gasoline prices but those of other goods as well. Consequently, this policy would have to be matched by programmes to ease the burden on the lower-income sectors that might be affected as higher gasoline prices fed through to increased prices for food or public transport, and thus require suitable compensation. 


\section{Bibliography}

Abreu, M. and R. Florax (2005), "A meta-analysis of B-convergence: the legendary 2\%", Journal of Economic Surveys, vol. 19, No. 3 , Wiley.

Alcaldía Mayor de Bogotá (2000), Decreto 1099 de 2000. Por el cual se toman medidas para el mejor ordenamiento del tránsito de vehículos en las vías públicas de Bogotá, D.C., Bogota.

Alves, D. and R. Bueno (2003), "Short-run, long-run and cross elasticities of gasoline demand in Brazil", Energy Economics, vol. 25, No. 2, Amsterdam, Elsevier.

Angrist, J.D. and J.S. Pischke (2009), Mostly Harmless Econometrics: An Empiricist's Companion, Princeton, Princeton University Press.

Apostol, T.M. (1967), Calculus, vol. 1, John Wiley \& Sons.

Bentzen, J. (1994), "An empirical analysis of gasoline demand in Denmark using cointegration techniques", Energy Economics, vol. 16, No. 2, Amsterdam, Elsevier.

Borenstein, M. and others (2009), Introduction to Meta-Analysis, John Wiley and Sons.

Brons, M. and others (2008), "A meta-analysis of the price elasticity of gasoline demand. A suR approach", Energy Economics, vol. 30, No. 5, Amsterdam, Elsevier.

Calthrop, E. and S. Proost (1998), "Road transport externalities", Environmental and Resource Economics, vol. 11, No. 3-4, Springer

Cnossen, S. (2005), Theory and Practice of Excise Taxation: Smoking, Drinking, Gambling, Polluting, and Driving, New York, Oxford University Press.

Cropper, M. and others (1997), "The health benefits of air pollution control in Delhi", American Journal of Agricultural Economics, vol. 79, No. 5, Agricultural and Applied Economics Association.

Cumming, G. (2012), Understanding the New Statistics: Effect Sizes, Confidence Intervals, and Meta-Analysis, New York, Routledge.

Dahl, C. (2012), "Measuring global gasoline and diesel price and income elasticities", Energy Policy, vol. 41, Amsterdam Elsevier.

(1992), "A survey of energy demand elasticities for the developing world", Journal of Energy Finance \& Development, vol. 18, No. 1, Amsterdam, Elsevier.

Deaton, A. and J. Muellbauer (1980), Economics and Consumer Behavior, Cambridge, Cambridge University Press

Doucouliagos, H. and T.D. Stanley (2009), "Publication selection bias in minimum-wage research? A meta-regression analysis", British Journal of Industrial Relations, vol. 47, No. 2, London, London School of Economics.

Egger, M. and others (1997), "Bias in meta-analysis detected by a simple, graphical test", British Medical Journal, vol. 315, No. 7109, BMJ Publishing Group.

Espey, M. (1998), "Gasoline demand revisited: an international metaanalysis of elasticities", Energy Economics, vol. 20, No. 3, Amsterdam, Elsevier.

European Commission (2014), Communication from the Commission to the European Parliament pursuant to Article 249(6) of the Treaty on the Functioning of the European concerning the position of the Council on the adoption of a Regulation of the European Parliament and of the Council on the sound level of motor vehicles (COM/2014/0107), Brussels.

Galindo, L.M. (2008), Estudio sobre la instrumentación de medidas de eficiencia energética y uso de biocombustibles en el sector transporte y su impacto en la calidad del aire en México. Informe Final, Mexico City, National Autonomous University of Mexico.

(2005), "Short- and long-run demand for energy in Mexico: a cointegration approach", Energy Policy, vol. 33, No. 9, Amsterdam, Elsevier.

Gately, D. (1992), "Imperfect price-reversibility of world oil demand", Energy Journal, vol. 14, No. 4, International Association for Energy Economics.

Goldberg, P.K. (1998), "The effects of the corporate average fuel economy standards in the U.S.", Journal of Industrial Economics, vol. 46, No. 1, Wiley.
Gómez-Ibáñez, J.A. and G.R. Futh (1980), "Downtown auto restraint policies. The costs and benefits for Boston", Journal of Transport Economics and Policy, vol. 14, No. 2, University of Bath/London School of Economics and Political Science.

Goodwin, P.B. (1992), "A review of new demand elasticities with special reference to short and long run effects of price changes", Journal of Transport Economics and Policy, vol. 26, No. 2, University of Bath/London School of Economics and Political Science.

Graham, D. and S. Glaister (2002), "The demand for automobile fuel a survey of elasticities", Journal of Transport Economics and Policy, vol. 36, No. 1, University of Bath/London School of Economics and Political Science.

Hanly, M. and others (2002), Review of Income and Price Elasticities in the Demand for Road Traffic, London, University College London.

Havranek, T. and others (2012), "Demand for gasoline is more priceinelastic than commonly thought", Energy Economics, vol. 34, No. 1, Amsterdam, Elsevier.

Heckman, J.J. (1979), "Sample selection bias as a specification error", Econometrica, vol. 47, No. 1, New York, The Econometric Society.

Hernández, F. and A. Antón (2013), "Optimal gasoline tax in developing, oil-producing countries: the case of Mexico", Working Paper, No. 555, Mexico City, Economic Research and Teaching Centre.

Kayser, H.A. (2000), "Gasoline demand and car choice: estimating gasoline demand using household information", Energy Economics, vol. 22, No. 3, Amsterdam, Elsevier.

Kim, Y.D. and others (2011), "The empirical effects of a gasoline tax on $\mathrm{CO}^{2}$ emissions reductions from transportation sector in Korea", Energy Policy, vol. 39, No. 2, Amsterdam, Elsevier.

Lipsey, M.W. and D.B. Wilson (2001), Practical Meta-Analysis, Thousand Oaks, Sage Publications.

Lozano, N. (2004), "Air pollution in Bogotá, Colombia: a concentrationresponse approach", Desarrollo y Sociedad, No. 54, Bogota, Universidad de los Andes.

Markandya, A. and A. Shibli (1995), "Industrial pollution control policies in Asia", Environment Discussion Paper Series, No. 3, Cambridge, Massachusetts, Harvard Institute for International Development.

Parry, I. and J. Strand (2010), "International fuel tax assessment: an application to Chile", Discussion Papers, No. 10-07, Washington, D.C., Resources for the Future.

Paterson, B.L. and C. Canam (2001), Meta-Study of Qualitative Health Research: A Practical Guide to Meta-Analysis and Meta-Synthesis, SAGE Publications.

Phillips, J.M. and E.P. Goss (1995), "The effect of state and local taxes on economic development: a meta-analysis", Southern Economic Journal, vol. 62, No. 2, Chattanooga, Southern Economic Association.

Pock, M. (2007), "Gasoline and diesel demand in Europe: new insights", Economics Series, No. 202, Institute for Advanced Studies.

Reyes, M.O. (2009), "La demanda de gasolinas en México: efectos y alternativas ante el cambio climático", Working Paper, Barcelona, Autonomous University of Barcelona.

Rietveld, P. (1994), "Spatial economic impacts of transport infrastructure supply", Transport Research, vol. 28, No. 4, Amsterdam, Elsevier.

Saez, M. and others (2001), "Comparing meta-analysis and ecologicallongitudinal analysis in time-series studies. A case study of the effects of air pollution on mortality in three Spanish cities", Journal of Epidemiology \& Community Health, vol. 55, No. 6

Schipper, Y.J.J. (1996), "On the valuation of aircraft noise: a metaanalysis", Zurich, European Regional Science Association [online] http://www-sre.wu.ac.at/ersa/ersaconfs/ersa96/ SESSION.D/d217.pdf.

Stanley, T.D. (2008), "Meta-regression methods for detecting and estimating empirical effects in the presence of publication selection", Oxford Bulletin of Economics and Statistics, vol. 70, No. 1, Oxford, University of Oxford. 
(2005), "Beyond publication bias", Journal of Economic Surveys, vol. 19, No. 3, Wiley.

(2001), "Wheat from chaff: meta-analysis as quantitative literature review", Journal of Economic Perspectives, vol. 15, No. 3, Nashville, Tennessee, American Economic Association.

Stanley, T.D. and H. Doucouliagos (2012), Meta-Regression Analysis in Economics and Business, Routledge.

(2011), "Meta-regression approximations to reduce publication selection bias", Economics Series, No. 2011/4, Deakin University.

Stanley, T.D. and S.B. Jarrell (1989), "Meta-regression analysis: a quantitative method of literature surveys", Journal of Economic Surveys, vol. 3, No. 2, Wiley.

Steenhof, P. and others (2006), "Greenhouse gas emissions and the surface transport of freight in Canada", Transportation Research Part D: Transport and Environment, vol. 11, No. 5, Amsterdam, Elsevier.

Sterne, J.A.C. (2009), Meta-Analysis in stata: An Updated Collection from the stata Journal, Texas, STATA Press.

Sterne, J.A.C. and M. Egger (2001), "Funnel plots for detecting bias in meta-analysis: guidelines on choice of axis", Journal of Clinical Epidemiology, vol. 54, No. 10, Amsterdam, Elsevier.
Sterne, J.A.C. and others (2000), "Publication and related bias in meta-analysis: power of statistical tests and prevalence in the literature", Journal of Clinical Epidemiology, vol. 53, No. 11, Amsterdam, Elsevier.

Sterner, T., C. Dahl and M. Franzén (1992), "Gasoline tax policy, carbon emissions and the global environment", Journal of Transport Economics and Policy, vol. 26, No. 2, University of Bath/London School of Economics and Political Science.

Van den Bergh, J.C. and others (2010), Meta-Analysis in Environmental Economics, Springer Science Business Media, B.V.

Varian, H.R. (1993), Análisis microeconómico, Barcelona, Antoni Bosch Editor.

Verhoef, E. (1994), "External effects and social costs of road transport", Transportation Research Part A: Policy and Practice, vo1. 28, No. 4, Amsterdam, Elsevier.

Williams, R.L. (2000), "A note on robust variance estimation for cluster-correlated data", Biometrics, vol. 56, No. 2, Wiley.

Wooldridge, J.M. (2002), Econometric Analysis of Cross Section and Panel Data, Cambridge, Massachusetts, The MIT Press. 